\title{
Geophysical Assessment of Impact of E-Waste Pollutants on the Subsurface Soil of Alaba International Market Dumpsite in Lagos, Nigeria.
}

PAUL ADENIRAN AJAKAYE ( $\square$ pajakaye@yahoo.com )

LAGOS STATE UNIVERSITY, OJO, LAGOS STATE, NIGERIA https://orcid.org/0000-0003-2860-1898

Emmanuel Somoye

Lagos State University Faculty of Science

Lawal Owolabi

Lagos State University Faculty of Education

\section{Research}

Keywords: E-waste, geoelectric, geophysical, lithogic, resistivity, VES, 2D-Wenne

Posted Date: October 18th, 2021

DOl: https://doi.org/10.21203/rs.3.rs-898523/v1

License: (c) (i) This work is licensed under a Creative Commons Attribution 4.0 International License.

Read Full License 


\title{
GEOPHYSICAL ASSESSMENT OF IMPACT OF E-WASTE POLLUTANTS ON THE SUBSURFACE SOIL OF ALABA INTERNATIONAL MARKET DUMPSITE IN LAGOS, NIGERIA
}

\author{
Paul Adeniran Ajakaye ${ }^{a}$, Somoye Emmanuel ${ }^{b}$, Owolabi Lawal ${ }^{\mathrm{c}}$
}

\section{Paul Adeniran Ajakaye}

pajakaye@yahoo.com or paul.adeniran@gmail.com

Center for Environmental Study and Sustainable Development, Lagos State University,Ojo,Lagos, Nigeria

${ }^{\mathrm{b}}$ Department of Physics, Lagos State University, Ojo, Lagos, Nigeria.

${ }^{\mathrm{c}}$ Department of Science and Technology Education, Lagos State University, Lagos, Nigeria.

\begin{abstract}
Soil degradation forms a part of the significant impacts arising from indiscriminate disposal of ewaste. This study was aimed at assessing the magnitude of legacy contamination by e-waste, particularly, its depth and spread in the subsurface soil of Alaba International Market e-waste dumpsite, Lagos, Nigeria through the analysis of VES and 2D-Wenner array configuration data acquired on the dumpsite. The results of the VES data and 2D resistivity analysis showed that Alaba dumpsite was highly impacted by the e-waste due to the permeable geoelectric characteristics of the lithologic units beneath the dumpsite. The lithogy enables the pollutants to spread laterally and progressively increase in depth through the sand column subsurface to more than $30 \mathrm{~m}$. It also showed that the contaminated zones are characterised by resistivity values ranging from 5.0 to $8.3 \Omega \cdot \mathrm{m}$. The study site is highly populated with wells and boreholes as the main sources of water for the community, thus the findings from this study could facilitate Lagos State Government decisions on improving protection for groundwater resources around the study area.
\end{abstract}

Keywords: E-waste, geoelectric, geophysical, lithogic, resistivity, VES, 2D-Wenne 


\subsection{Introduction:}

Increasingly rapid evolution of information and communication technology (ICT), coupled with rapid product obsolescence have invariably led to increasing generation of electrical-electronic waste, usually referred to as 'e-waste'. It is a phenomenon that has been a challenge confronting the world economy since the 1990s (Okwu and Onyeje, 2014). A UN report recorded that the quantity of e-waste generated in 2016, globally, amounts to 44.7 million metric tonnes, up by 3.3 Mt or 8 percent (annual growth rate of 3-5\%) from 2014 (Leblanc, 2018; UNU, 2017). It is likely, therefore, that municipalities or authorities which are responsible for waste management in the cities may not be able to perform efficiently and effectively, particularly, if the authority is bogged down by ineffective organizational structure, inadequate financial resources, undue complexity and system multi dimensionality (Ravi and Vishnudas, 2017; Zohoori and Ghani, 2017).

In the case of Nigeria, it was reported by UNIDO (2014) that every year, the amount of e-wastes that enter the country unlawfully through Apapa and Tincan seaports, Lagos airport (MMIA); and other ports in the country is about 100,000 tonnes of e-wastes enter the country unlawfully. The said report stated further that Nigeria generates (1.1 million tonnes of e-waste) annually and invariably, more than the total volume of e-wastes being generated by all other countries in the ECOWAS region combine together (The Guardian, 2018). But, like many of the developing countries; Nigeria is bereaved of a functional structure that can enable a cross cutting edge in ewaste management. The general population is invariably exposed to e-waste scenarios leading to all kinds both environmental and health risks.

Determining e-waste pollutants depth and spread or contamination zones in dumpsite soil is a way of providing valuable information about the quantity and toxicity effects of the pollutants to 
the environment and human health. The aim of this study is to provide an appreciable understanding and information about the level of impact of e-waste pollutants with soil of Alaba International Market, Lagos, Nigeria and to enable policy implementers to initiate necessary and appropriate remediation methods as part of the solutions to the Lagos State environmental sustainability problem, particularly, as it concerns indiscriminate disposal and crude recycling methods of e-wastes.

\subsection{Field description}

The e-wastes dumpsite (see base map in Fig. 1) which is about $100 \mathrm{~m}^{2}$ in size is located at Alaba International Market, Ojo Local Government Area, Lagos State, Nigeria. It has been in existence for more than 20 years as a dumpsite where e-waste collectors and recyclers work, live in sheds and indulge in burning and other crude methods of recycling in an attempt to extract valuable components of e-waste albeit, without care for their health or environment. The devices generating the e-wastes are mostly imported second-hand electrical-electronics products.

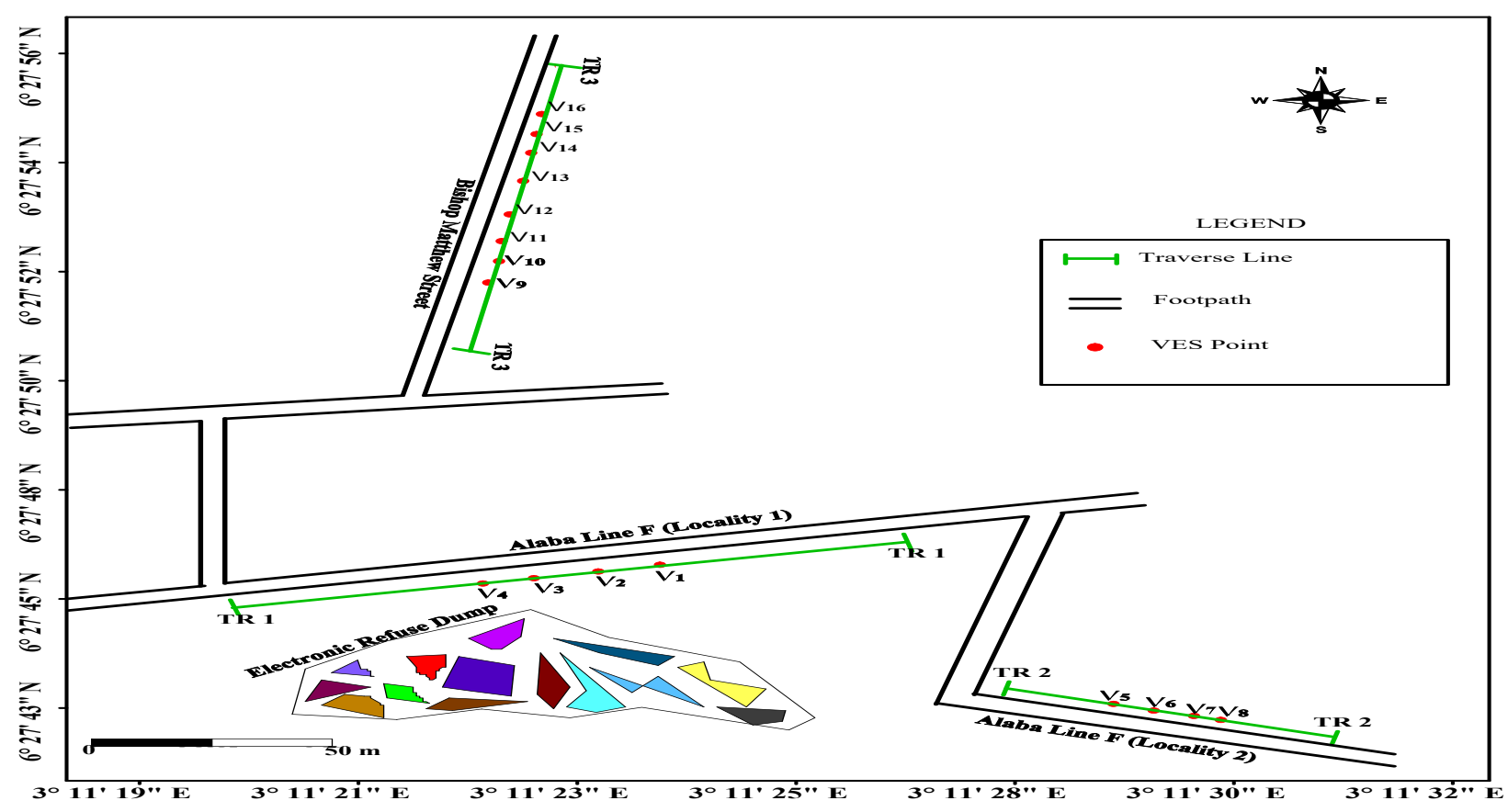

Fig. 1: Base map for Alaba International Market dumpsite 


\subsection{Local geology/geomorphology of Lagos state:}

Lagos State lies within the geographic coordinates of Lat.: $\mathrm{N}^{\circ} 6^{\circ} 23^{\prime}$ and $\mathrm{N}^{\circ} 6^{\circ} 40^{\prime}$ and Long.: $\mathrm{E} 03^{\circ} 13^{\prime}$ and $\mathrm{E} 03^{\circ} 27^{\prime}$ (Oladapo et al., 2013). It is within the Euro - African sector of the world in the neighbourhood of the Greenwich Meridian (Somoye, 2017).

Experts have described the local geology/geomorphology of Lagos State as follows;

Lagos is underlain by the Dahomey Basin with lithologic constituents that are mainly sands, clays and limestones. The basement complex which forms the basement rocks in the basin is overlain in succession by the Cretaceous Abeokuta Formation which is sandy with inter-bedded shales and limestone formation. Following it is the Tertiary Ewekoro Formation comprising of limestone, clays and shales and the Ilaro formation consisting of clays and shales followed by the poorly sorted coastal plain sands and recent alluvial deposits. The latter which consists of lithoral and lagoonal sediments of the coastal belt is characterized by mangrove (saltwater) and freshwater swamps where aquifers, are readily recharged by copious rainfall thus making them vulnerable to leachate contamination in areas proximal to landfills (Akinlalu and Afolabi, 2018; Odukoya, 2015).

\subsection{Materials and methods}

\subsection{Sample coverage:}

Geophysical investigation involving 2-D electrical resistivity imaging (ERI) via Wenner array configuration and 1-D Vertical Electrical sounding adopting Schlumberger array was carried out along predetermined traverses within the study area. The 2-D resistivity data were collected at inter-electrode spacing of $10 \mathrm{~m}$ along some traverses and $5 \mathrm{~m}$ at other traverses as shown in Table 1. The varied inter-electrode spacing was due to constraint in available space within the study areas which had developed to communities. A total of three traverses were occupied.

Along each traverse, four VES were acquired at predetermined stations except on traverse three where it was possible to acquire eight (8) VES because of the available space. Thus, 16 VES were acquired in all as shown in (Table 1). 
Table 1:

Traverse spacing and number of vertical electrical sounding

\begin{tabular}{|l|l|l|l|l|}
\hline TRAVERSE & $\begin{array}{l}\text { ELECTRODE } \\
\text { SPACING (m) }\end{array}$ & $\begin{array}{l}\text { TRAVERSE } \\
\text { LENGTH (m) }\end{array}$ & NO. OF VES & $\begin{array}{l}\text { COORDINATE } \\
\text { Lat. (N)/Long. (E) }\end{array}$ \\
\hline Alaba & 10 & 200 & 4 & $6^{0} 27^{\prime} 45.8^{\prime \prime} / 003^{0} 11^{\prime} 26.5^{\prime \prime}$ \\
\hline 1 & 5 & 100 & 4 & $6^{0} 27^{\prime} 43.6^{\prime \prime} / 003^{0} 11^{\prime} 27.5^{\prime \prime}$ \\
\hline 2 & 10 & 200 & 8 & $6^{0} 27^{\prime} 50.3^{\prime \prime} / 003^{0} 11^{\prime} 22.2^{\prime \prime}$ \\
\hline 3 & & & 8 &
\end{tabular}

\subsection{Sampling technique:}

In this study, the Electrical Resistivity Imaging techniques which involve the Vertical Electrical Sounding (Schlumberger) and 2D-Wenner were adopted as a result of their less sensitivity to noise; and good vertical and lateral resolution and coverage respectively.

For the Schlumberger array, four electrodes were placed in line around a common midpoint. The two outer electrodes, A and B, form the current electrodes, while the two inner electrodes, M and $\mathrm{N}$ that were placed close together constitute the potential electrodes (Alabi et al., 2010; Dulaymi et al., 2012). Now, for each measurement; the current electrodes A and B were moved outward to a greater separation continuously throughout the survey, while the potential electrodes $\mathrm{M}$ and $\mathrm{N}$ remained in the same position until the observed voltage becomes too small to be measured (Ohaegbuchu et al., 2019). At this point, the potential electrodes $\mathrm{M}$ and $\mathrm{N}$ are further moved outward to a new spacing. Essien et al., (2020) suggested, as a rule of the thumb that; "the reasonable distance between $\mathrm{M}$ and $\mathrm{N}$ should be equal or less than one-fifth of the distance between A and B at the beginning." The ratio thus goes up to about one-tenth or one-fifteenth 
depending on the strength of the signal. The Schlumberger method will enable the determination of the depth of the pollutants zone in the dumpsite soil.

In the 2D (Wenner) array, geo-electrical resistivity imaging is achieved when the VES techniques and that of electrical profiling were integrated (Aizebeokhai, 2010). The apparent resistivities were measured from electrodes placed along a line using a range of different electrode separations and mid-points. The procedure was then repeated for as many combinations of current and potential electrode positions based on the survey configuration, that is, as a combination of successive profiles that go with increasing spacing of the electrode. The 2D-Wenner array gives adequate information on the spread of the pollutants zone in the dumpsite soil.

\subsection{Soil geophysical equipment and materials:}

Equipment and materials used in this study include:

- PASI Earth Resistivity Meter: P100-2N; 16GL terrameter (see Plate 1) consisting of a constant current source (commonly a battery pack connected to a commutated direct current (DC) circuit to change polarity of the current source); an ammeter which measures the injecting current; a very sensitive voltmeter that measures the response signal; four metal stake electrodes usually stainless steel or non-polarising $\mathrm{Cu}-\mathrm{CuSO}_{4}$ and $\mathrm{Ag}-\mathrm{AgCl}_{2}$ which ensures low impedance characteristic.

- Four cable for connecting electrodes to the current source and voltmeter .

- 12 volts Battery (DC)

- Hammer

- Measuring tapes 
- Resistivity sounding field records (Data sheet)

- Cutter or razor blade

- GARMIN etrex 10 - Global Positioning System (GPS) to geo-reference the data points.

- Log-log graph, tracing paper, master curve (Schlumberger), ha auxiliary and kq auxiliary curves for sequent by sequent matching method of processing the Schlumberger array data.

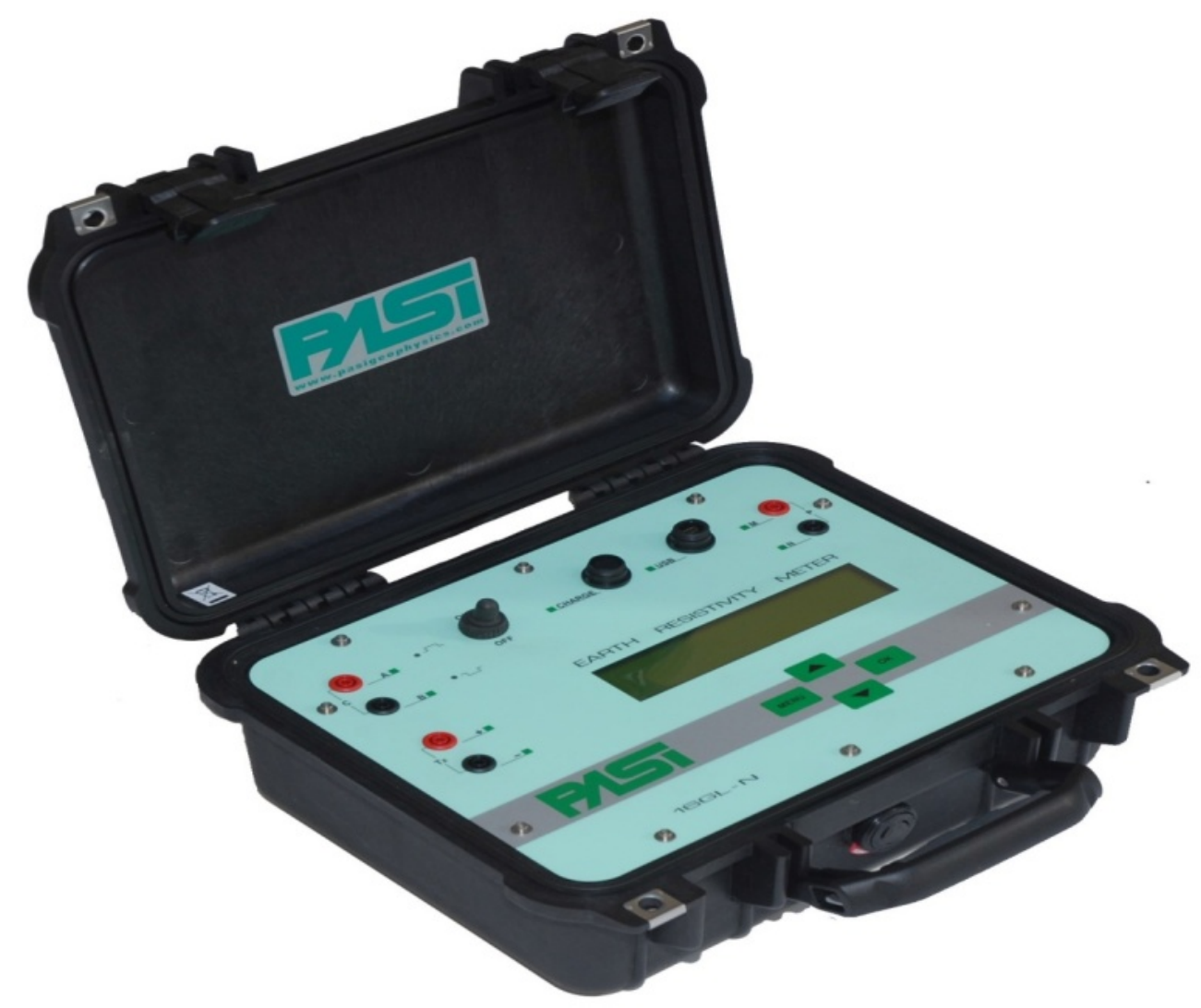

Plate 1: PASI earth resistivity meter: P100-2N; 16GL terrameter

\subsection{Data analysis}

The curve matching (observing the shape of the field curve) method was used to interprete the sub-surface resistivity distribution. A curve is drawn by plotting apparent resistivity against electrode spacing; field curve was then matched with the master curve for qualitative interpretation (Coker, 2012). Subsequently, the VES data were processed using segment by 
segment curve matching through which the geoelectric models of the subsurface were generated. The distributions of resistivities of different subsurface layers $(\rho)$ were classified, based on curve shapes, in a three-layered earth model.

The whole set of three-layer sounding curves were divided into four groups, depending on the relative values of $\rho 1, \rho 2$, and $\rho 3$ (Anudu et al., 2014; Vasantrao et al., 2017).

i. Minimum type: When $\rho 1>\rho 2<\rho 2<\rho 3$ i.e H-type (from the name - Hummel)

ii. Double-ascending type: When $\rho 1<\rho 2<\rho 3$ i.e A-type (from the term anisotropy)

iii. Maximum type: When $\rho 1 \rho 3$ i.e K-type or DA-type (implying displaced or modified anisotropy).

iv. Double descending type: When $\rho 1>\rho 2>\rho 3$ i.e Q-type or DH-type (meaning displaced Hummel or modified Hummel).

A combination of the curves of the three-layer type (i.e. H, A, K, and Q), the four-layered curves; HA type $(\rho 1>\rho 2<\rho 3<\rho 4)$; HK type $(\rho 1>\rho 2<\rho 3>\rho 4)$; KH type; QH type $(\rho 1>\rho 2>\rho 3<\rho 4)$ etc could be produced. These models were fed into the Winresist (version 1.0, C.1998, 2004) software along with the field data to undergo iteration and obtain the best fit between the field data and the calculated models. This process yielded the true resistivity of the subsoil layers, their thicknesses and depth which became useful for generating the geoelectric sections of the subsurface along each traverse.

The acquired 2-D resistance data were multiplied by the geometric factor and then fed into Diprofwin software for inversion and 2-D resistivity images of the subsurface to show the pollutant plumes along the traverses. The results from both 2-D ERI and VES were integrated to 
determine the extent of impact of pollutants at the e-waste dumpsites in the same manner of investigation by Vasantrao et al., (2017).

\subsection{Results and Discussions}

\subsection{Geoelectric section (VES) of Alaba dumpsite soil:}

Sounding curve types obtained at Alaba were H, KH, A, HK, QH and K (see Fig. 2 and Table 2).

The iteration of these curve types led to the identification of the geoelectrical section or nature of the dumpsite subsurface soil.

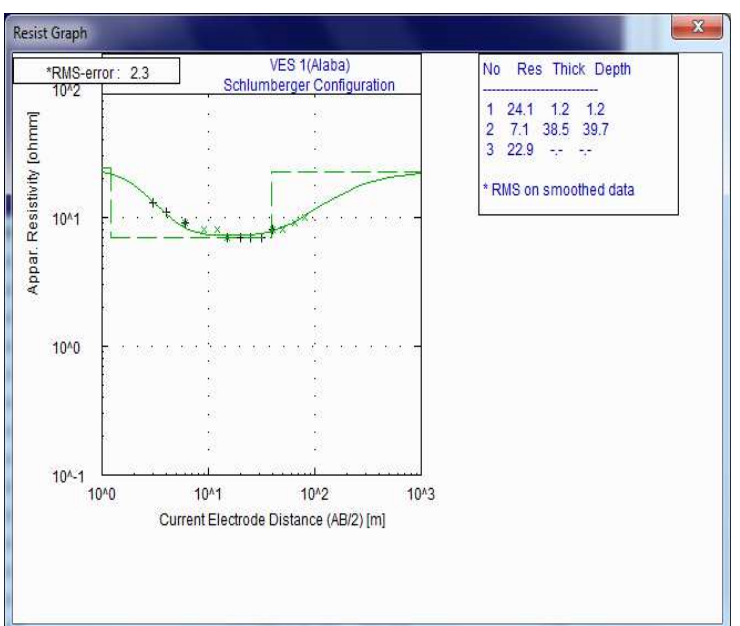

H type: $\rho 1>\rho 2<\rho 3$ curve

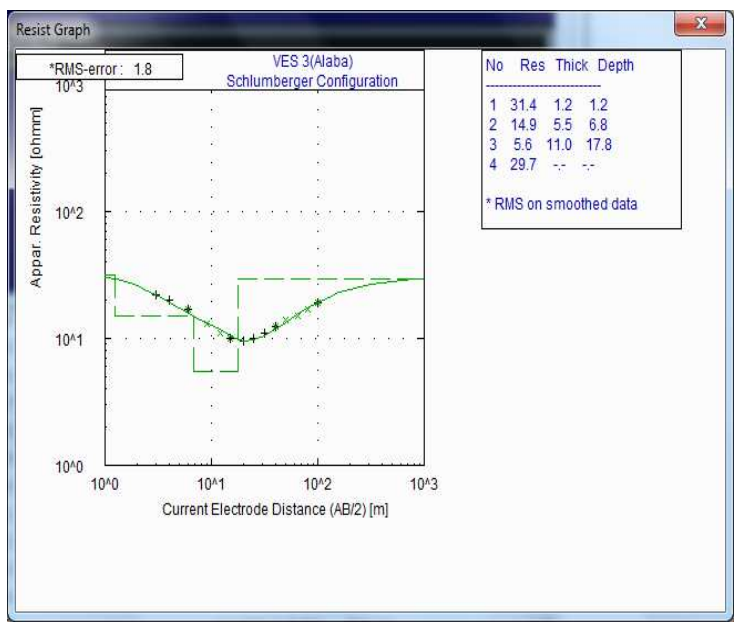

KH type: $\rho 1>\rho 2>\rho 3<\rho 4$ curve

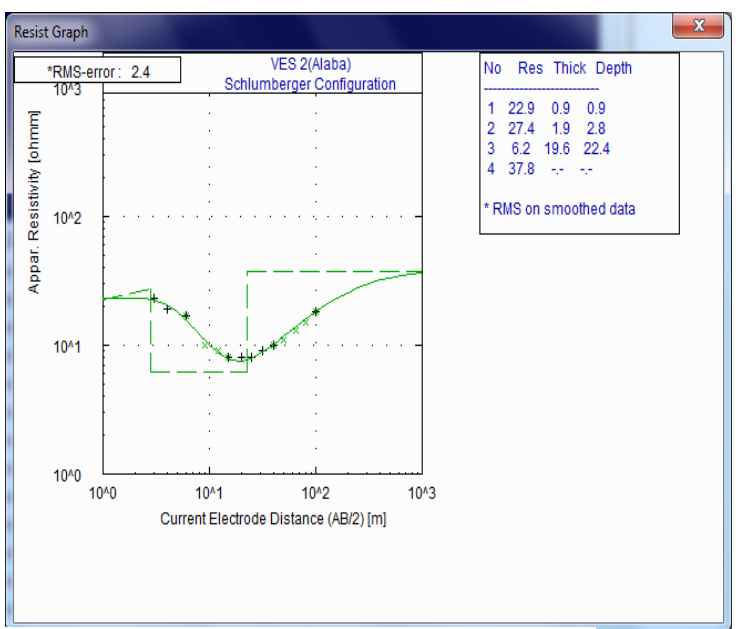

KH type: $\rho 1>\rho 2>\rho 3<\rho 4$ curve

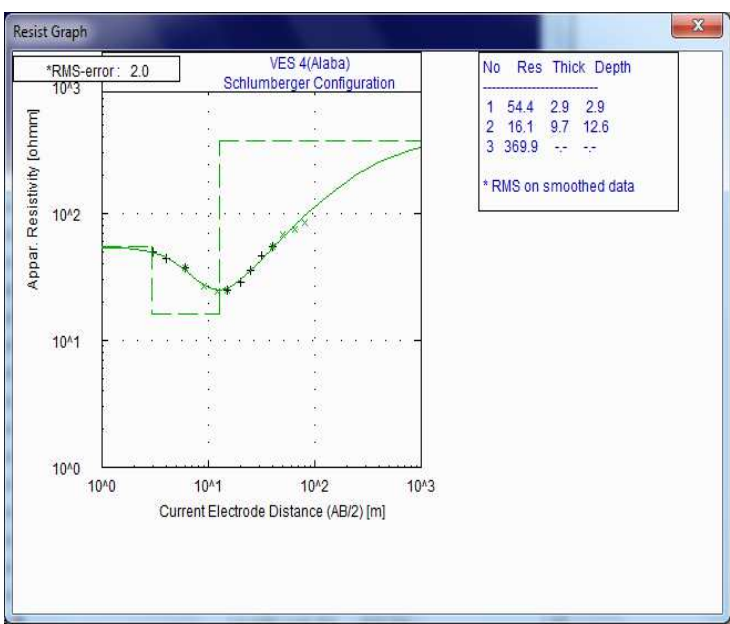

H type: $\rho 1>\rho 2<\rho 3$ curve

Fig. 2: VES curves 1 - 4 for Alaba international market dumpsite 


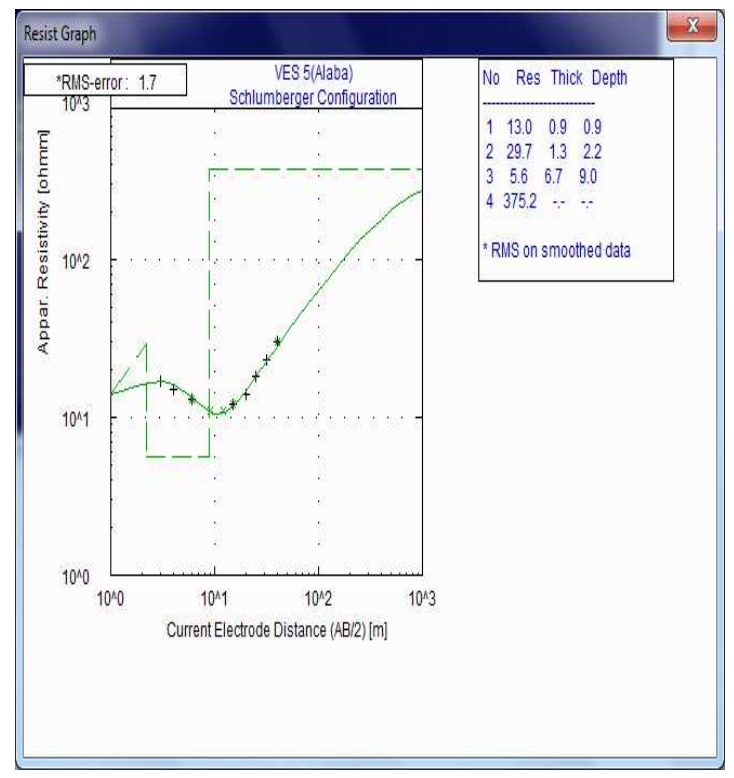

KH type: $\rho 1>\rho 2>\rho 3<\rho 4$ curve

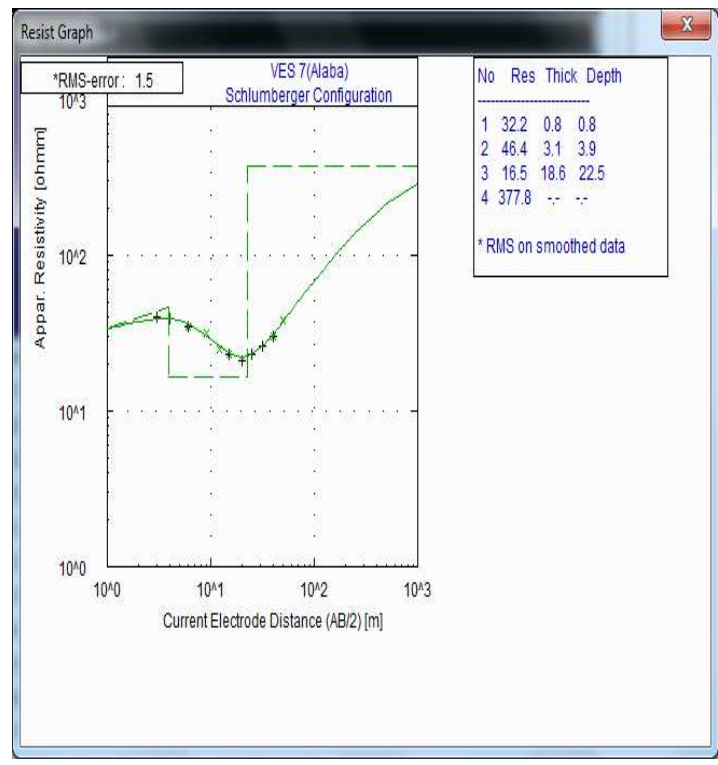

KH type: $\rho 1>\rho 2>\rho 3<\rho 4$ curve

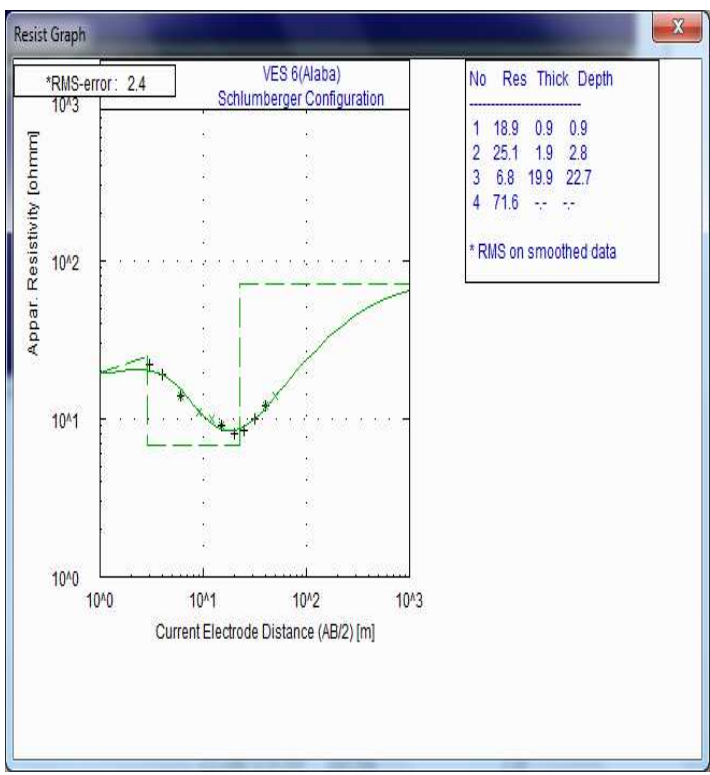

KH type: $\rho 1>\rho 2>\rho 3<\rho 4$ curve

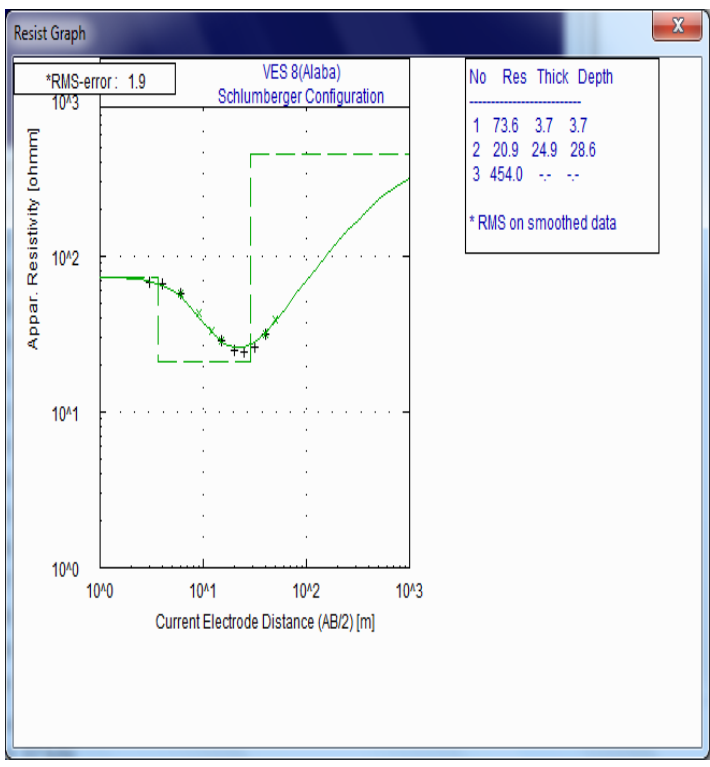

H type: $\rho 1>\rho 2<\rho 3$ curve

Fig. 2: VES curves 5 -8 for Alaba international market dumpsite 


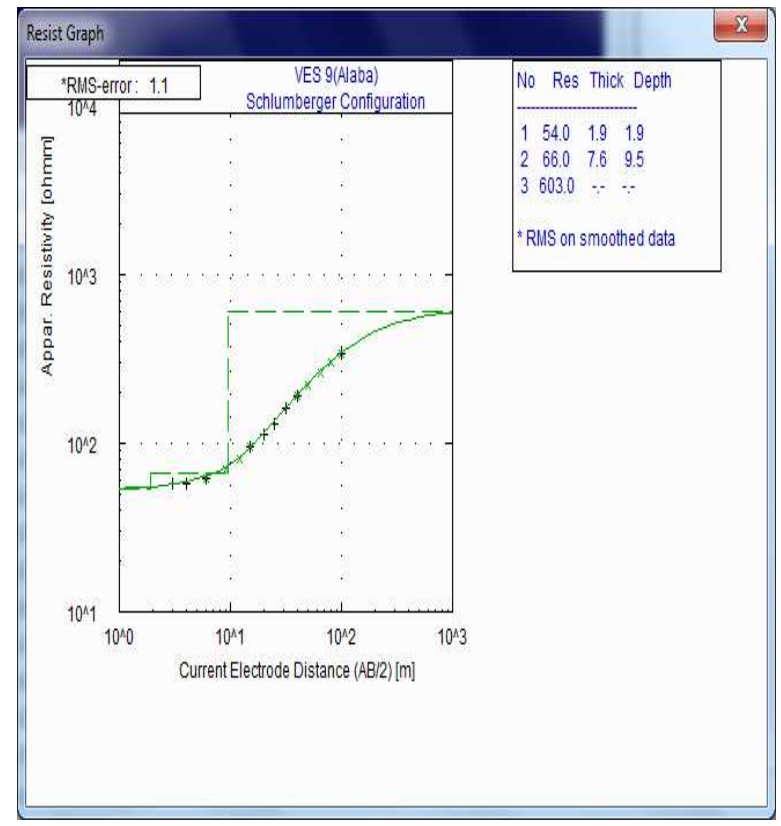

A type: $\rho 1<\rho 2<\rho 3$ curve

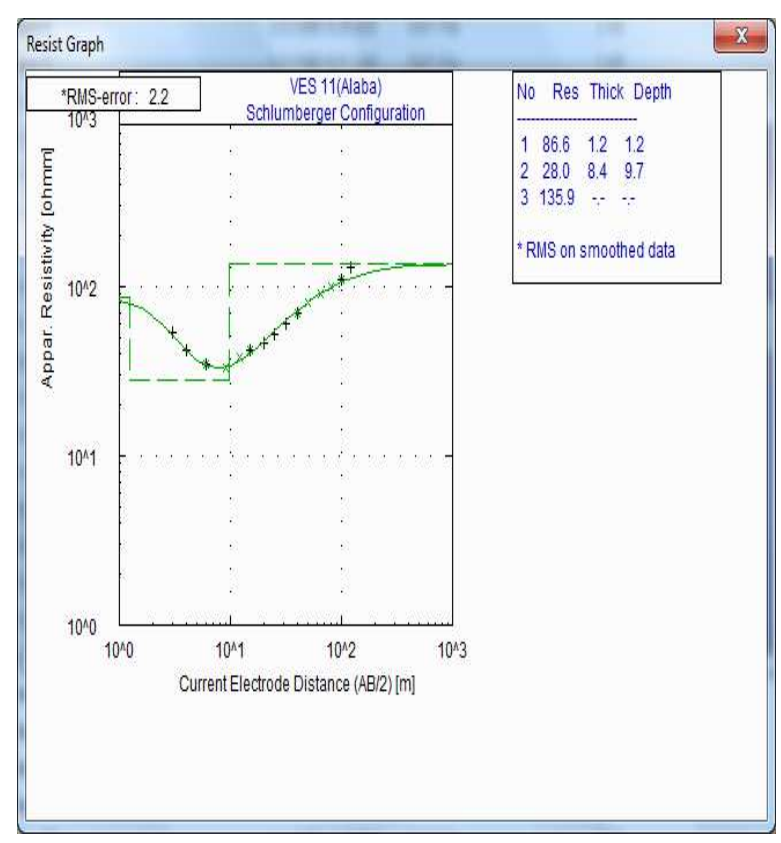

H type: $\rho 1>\rho 2<\rho 3$ curve

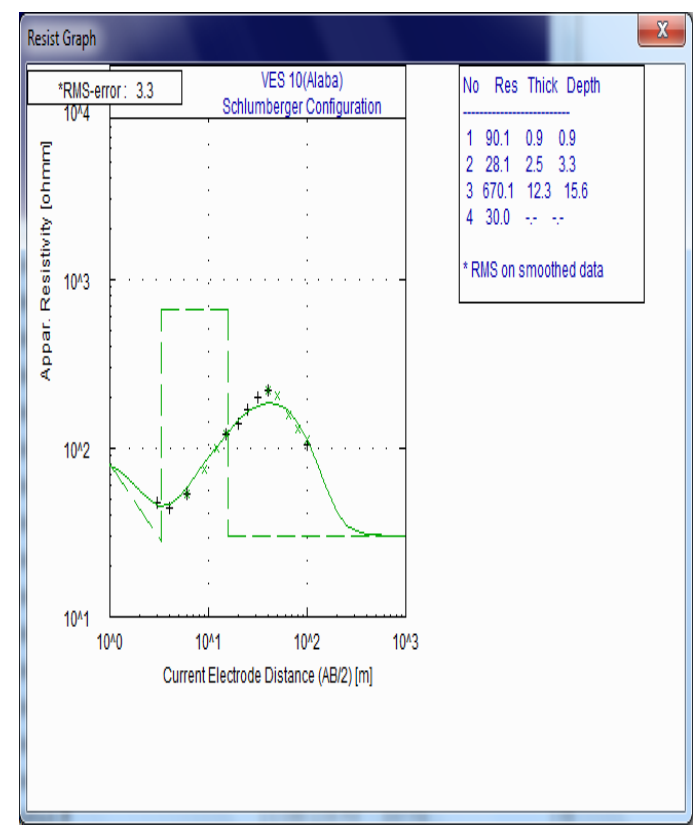

HK type: $\rho 1>\rho 2<\rho 3>\rho 4$ curve

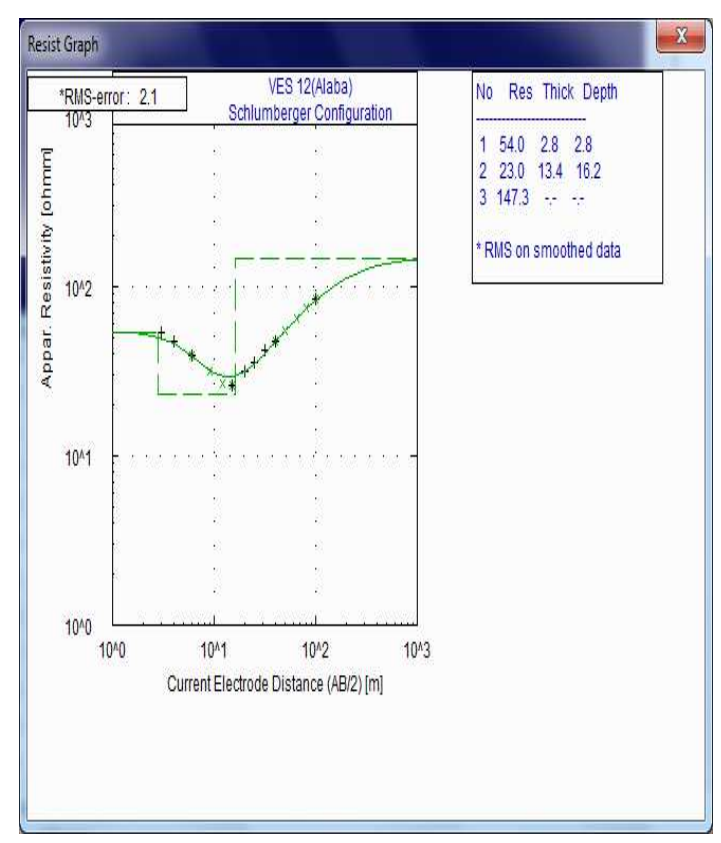

H type: $\rho 1>\rho 2<\rho 3$ curve

Fig. 2: VES curves 10 - 12 for Alaba international market dumpsite 


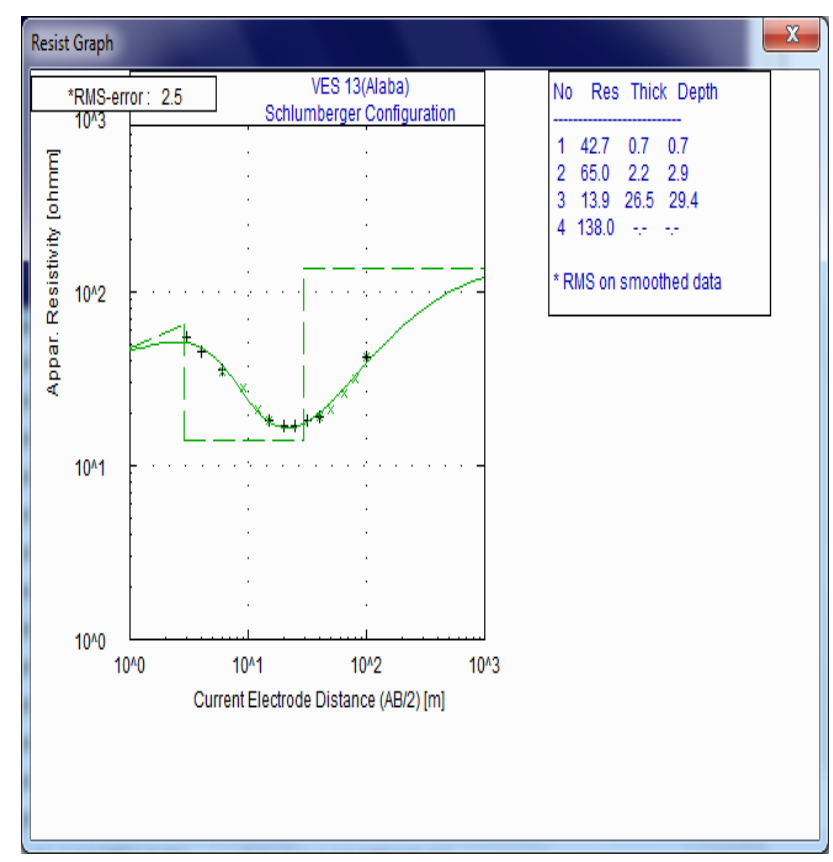

KH type: $\rho 1>\rho 2>\rho 3<\rho 4$ curve

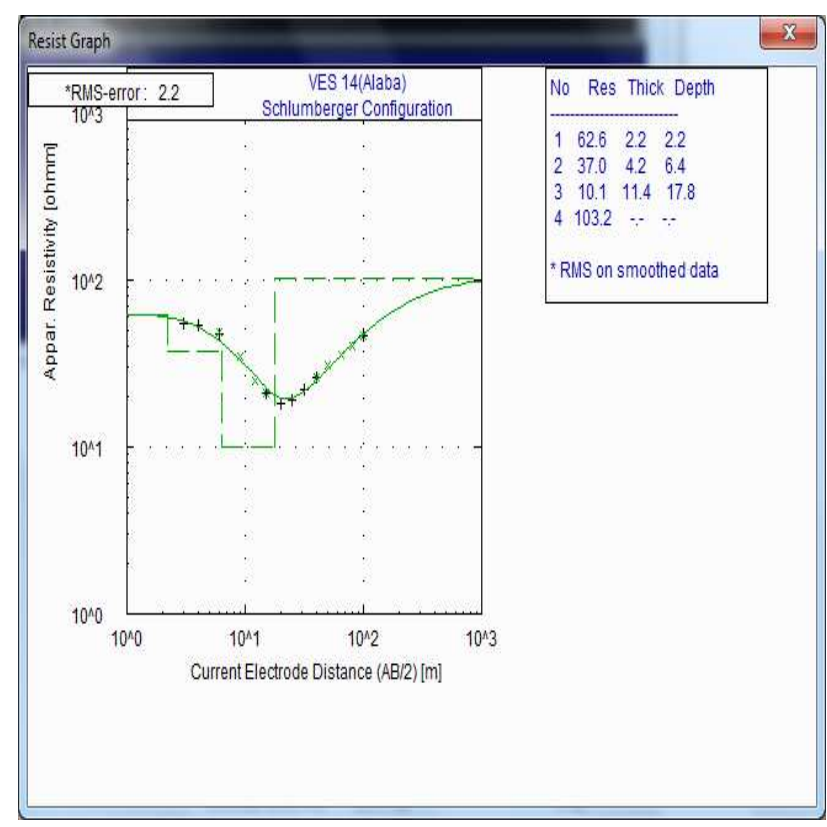

QH type: $\rho 1>\rho 2>\rho 3<\rho 4$ curve

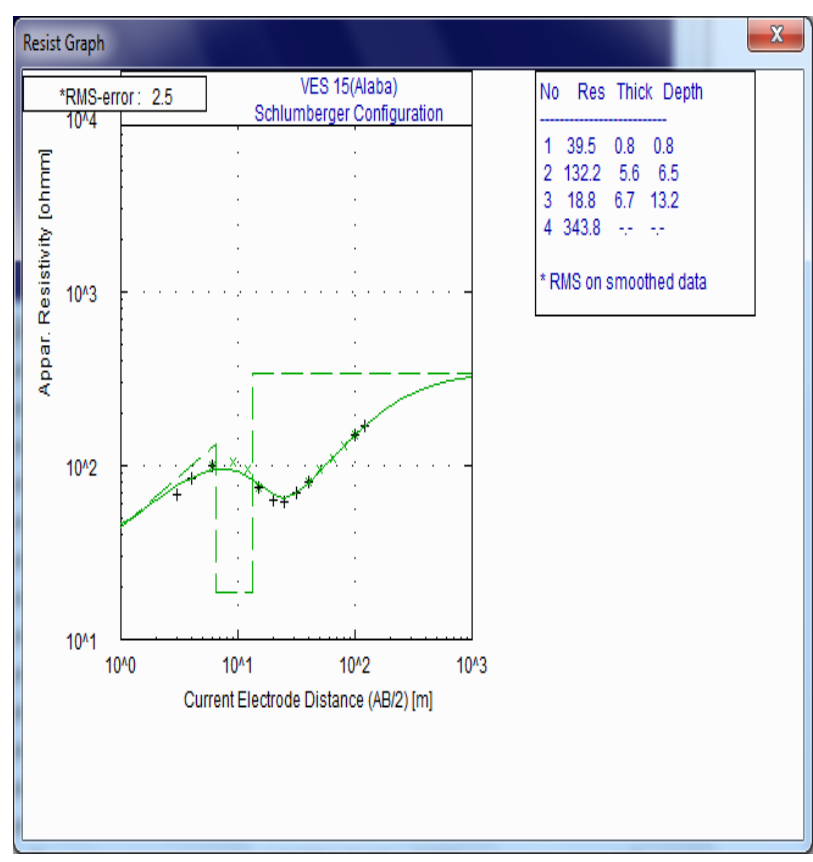

KH type: $\rho 1>\rho 2>\rho 3<\rho 4$ curve

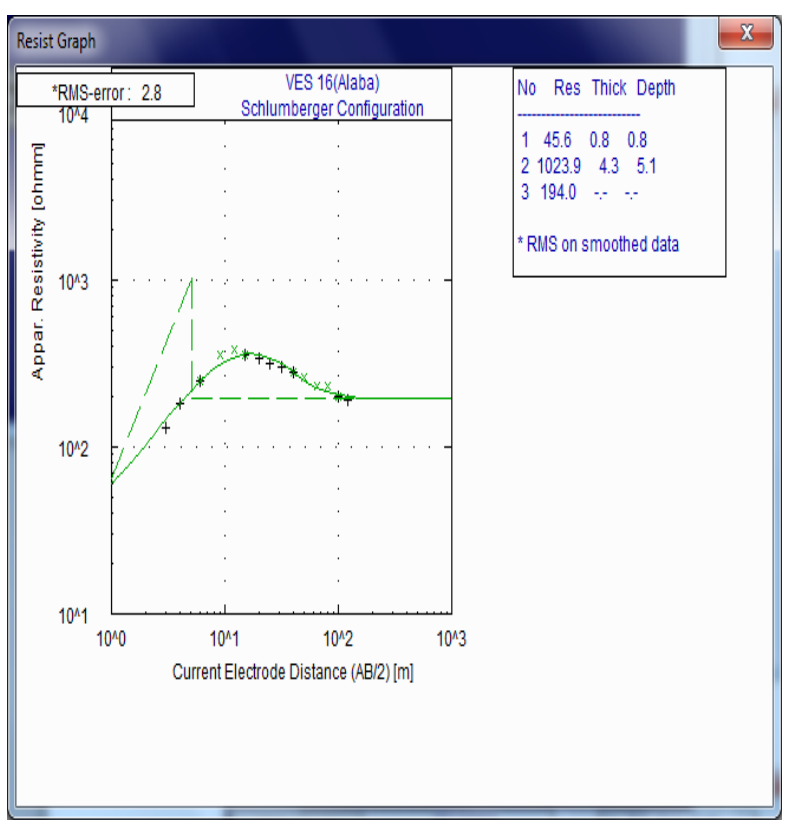

K type: $\rho 1<\rho 2>\rho 3$ curve

Fig. 2: VES curves 13 - 16 for Alaba international market dumpsite 
The summary of the curve types (VES 1 - VES 16) and site lithology is shown in Table 2.

Table 2:

Vertical electrical sounding summary of Alaba international market dumpsite

\begin{tabular}{|c|c|c|c|c|c|}
\hline VES NO & $\begin{array}{l}\text { RESISTIVITY } \\
\text { (ohm-m) }\end{array}$ & $\begin{array}{l}\text { THICKNESS } \\
\text { (m) }\end{array}$ & $\begin{array}{l}\text { DEPTH } \\
\text { (m) }\end{array}$ & LITHOLOGY & $\begin{array}{l}\text { CURVE } \\
\text { TYPE }\end{array}$ \\
\hline \multirow[t]{3}{*}{1} & 24 & 1.2 & 1.2 & Topsoil & \multirow[t]{2}{*}{$\mathbf{H}$} \\
\hline & 7 & 38.5 & 39.7 & Leachate & \\
\hline & 23 & -------- & -------- & Clay & \multirow[t]{5}{*}{ KH } \\
\hline \multirow[t]{4}{*}{2} & 23 & 0.9 & 0.9 & Topsoil & \\
\hline & 27 & 1.9 & 2.8 & Clay & \\
\hline & 6 & 19.6 & 22.4 & Leachate & \\
\hline & 38 & -------- & --------- & Clay & \\
\hline \multirow[t]{4}{*}{3} & 31 & 1.2 & 1.2 & Topsoil & \multirow[t]{4}{*}{ KH } \\
\hline & 15 & 5.5 & 6.8 & Clay & \\
\hline & 6 & 11 & 17.8 & Leachate & \\
\hline & 30 & 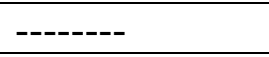 & 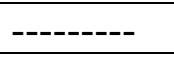 & Clay & \\
\hline \multirow[t]{4}{*}{4} & 31 & 1.2 & 1.2 & Topsoil & \multirow[t]{4}{*}{$\mathbf{H}$} \\
\hline & 54 & 2.9 & 2.9 & Topsoil & \\
\hline & 16 & 9.7 & 12.6 & Clay & \\
\hline & 370 & -------- & --------- & Sand & \\
\hline \multirow[t]{4}{*}{5} & 13 & 0.9 & 0.9 & Topsoil & \multirow[t]{4}{*}{ KH } \\
\hline & 30 & 1.3 & 2.2 & Clay & \\
\hline & 6 & 6.7 & 9 & Leachate & \\
\hline & 375 & --------- & --------- & Sand & \\
\hline \multirow[t]{4}{*}{6} & 19 & 0.9 & 0.9 & Topsoil & \multirow[t]{4}{*}{ KH } \\
\hline & 25 & 1.9 & 2.8 & Clay & \\
\hline & 7 & 20 & 23 & Leachate & \\
\hline & 72 & ------ & ------- & Sandy clay & \\
\hline \multirow[t]{4}{*}{7} & 32 & 0.8 & 0.8 & Topsoil & \multirow[t]{4}{*}{ KH } \\
\hline & 46 & 3.1 & 3.9 & Sandy clay & \\
\hline & 17 & 18.6 & 22.5 & Clay & \\
\hline & 378 & -------- & -------- & Sand & \\
\hline \multirow[t]{3}{*}{8} & 74 & 3.7 & 3.7 & Topsoil & \multirow[t]{3}{*}{$\mathbf{H}$} \\
\hline & 21 & 24.9 & 28.6 & Clay & \\
\hline & 454 & ------- & ------- & Sand & \\
\hline \multirow[t]{3}{*}{9} & 54 & 1.9 & 1.9 & Topsoil & \multirow[t]{3}{*}{$\mathbf{A}$} \\
\hline & 66 & 7.6 & 9.5 & Clayey sand & \\
\hline & 603 & -------- & -------- & Sand & \\
\hline \multirow[t]{2}{*}{10} & 90 & 0.9 & 0.9 & Topsoil & \multirow[t]{2}{*}{ HK } \\
\hline & 28 & 2.5 & 3.3 & Clay & \\
\hline
\end{tabular}




\begin{tabular}{|l|l|l|l|l|l|}
\hline \multirow{2}{*}{$\mathbf{1 1}$} & 670 & 12.3 & 15.6 & Sand & \\
\cline { 2 - 5 } & 30 & -------- & -------- & Clay & \\
\cline { 2 - 5 } & 87 & 1.2 & 1.2 & Topsoil & \multirow{3}{*}{} \\
\cline { 2 - 5 } & 28 & 8.4 & 9.7 & Clay & \\
\cline { 2 - 5 } & 136 & --------- & ------- & Sand & \\
\hline
\end{tabular}

\begin{tabular}{|c|c|c|c|c|c|}
\hline \multirow[t]{3}{*}{12} & 54 & 2.8 & 2.8 & Topsoil & \multirow[t]{3}{*}{ H } \\
\hline & 23 & 13.4 & 16.2 & Clay & \\
\hline & 147 & -------- & --------- & Sand & \\
\hline \multirow[t]{4}{*}{13} & 43 & 0.7 & 0.7 & Topsoil & \multirow[t]{4}{*}{ KH } \\
\hline & 65 & 2.2 & 2.9 & Sandy clay & \\
\hline & 14 & 27 & 29.4 & Clay & \\
\hline & 138 & -------- & --------- & Sand & \\
\hline \multirow[t]{4}{*}{14} & 63 & 2.2 & 2.2 & Topsoil & \multirow[t]{4}{*}{ QH } \\
\hline & 37 & 4.2 & 6.4 & Clay & \\
\hline & 10 & 11.4 & 17.8 & Clay & \\
\hline & 103 & ------- & - ------- & Sand & \\
\hline \multirow[t]{4}{*}{15} & 40 & 0.8 & 0.8 & Topsoil & \multirow[t]{4}{*}{ KH } \\
\hline & 132 & 5.6 & 6.5 & Sand & \\
\hline & 19 & 6.7 & 13.2 & Clay & \\
\hline & 344 & -------- & --------- & Sand & \\
\hline \multirow[t]{3}{*}{16} & 47 & 0.8 & 0.8 & Topsoil & \multirow[t]{3}{*}{$\mathbf{K}$} \\
\hline & 1024 & 4.3 & 5.1 & Sand & \\
\hline & 194 & -------- & ---------- & Sand & \\
\hline
\end{tabular}

The results of the vertical electrical sounding (see Figure. 3 a, b, c \& d) revealed that the geoelectric section of Alaba dumpsite consists mostly three subsurface layers composed of clay column, clayey sand and sand which allows a high level of impact of the dumpsite soil.

a)

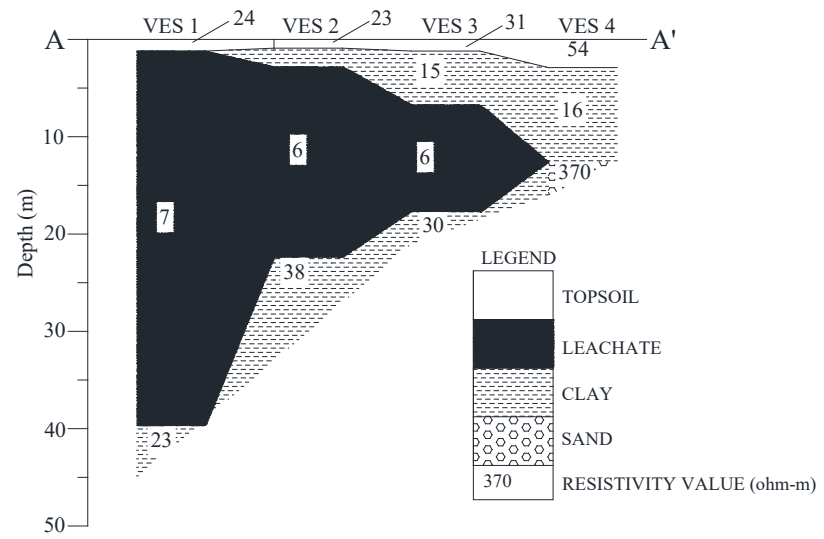


b)

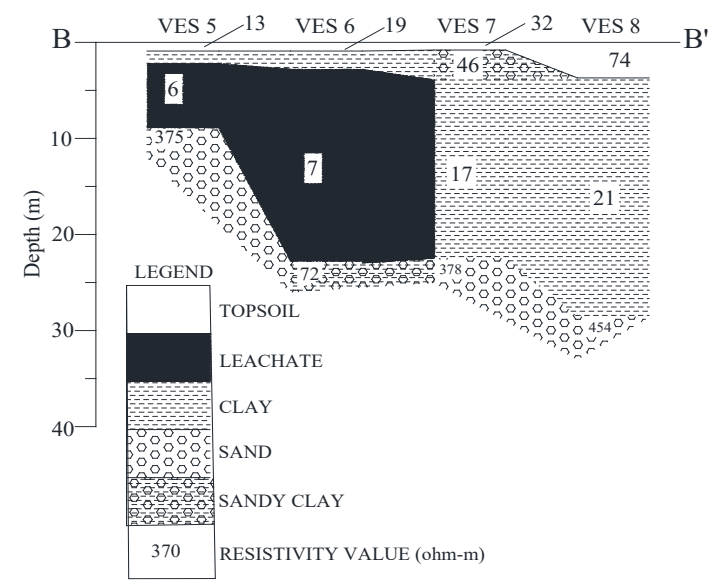

c)

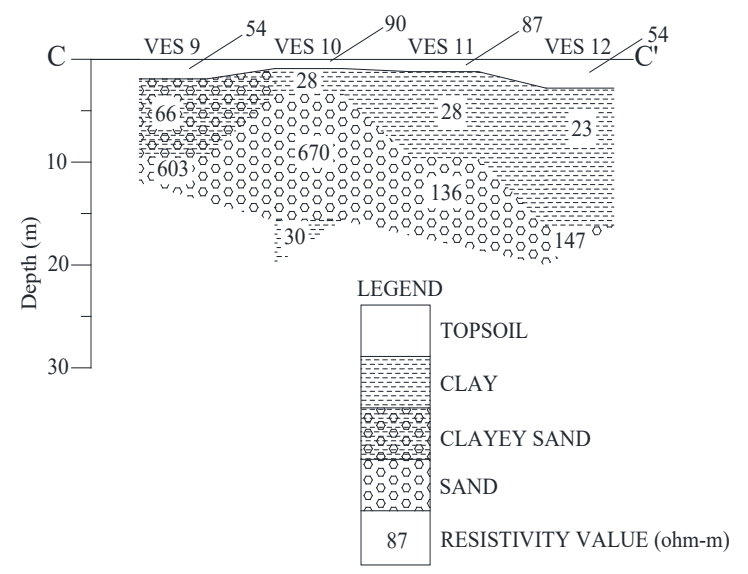

d)

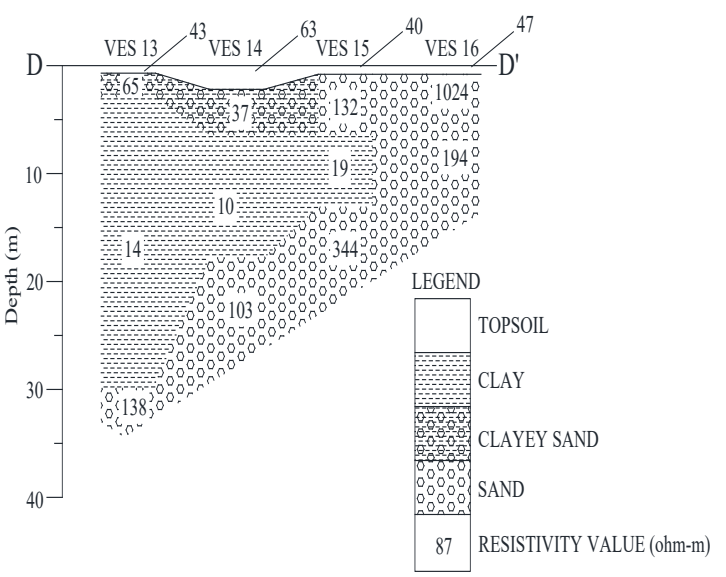

Fig. 3 (a- d): Geoelectric sections of Alaba dumpsite 


\subsection{Depths and spread of pollutants in Alaba dumpsite soil based on the 2D Wenner array:}

The result from the 2D Wenner array profiles for Alaba indicated that the soil was highly impacted by e-waste. The finding was based on three profiles that were obtained from the dumpsite. The profiles were as follows:

Profile 1: The profile (see Fig. 4) was to the north of the dumpsite along Alaba F-Line Locality 1 (see Fig. 1). Two impacted zones of very low resistivity value of $5 \Omega \cdot \mathrm{m}$ were observed. The first zone starts from the ground surface and migrated to about $5 \mathrm{~m}$ depth at a lateral distance up to $45 \mathrm{~m}$. The low value of resistivity at the end of the spectrum revealed the real nature of the contaminant plume. The second highly impacted zone spread at a lateral distance of about $83-$ $155 \mathrm{~m}$ on the topsoil and then increasingly percolates the soil through a narrow gauge between a lateral distance of about $85-105 \mathrm{~m}$ reaching a depth of more than $30 \mathrm{~m}$.

Also observed was a no impact zone having resistivity value of $55 \Omega . \mathrm{m}$. The zone dominated a lateral distance from about $105-180 \mathrm{~m}$ from a depth of about $10 \mathrm{~m}$ to more than $30 \mathrm{~m}$. The relatively high resistivity value spectrum corresponds to the clay column identified in the geoelectric section of VES 1 -4. 


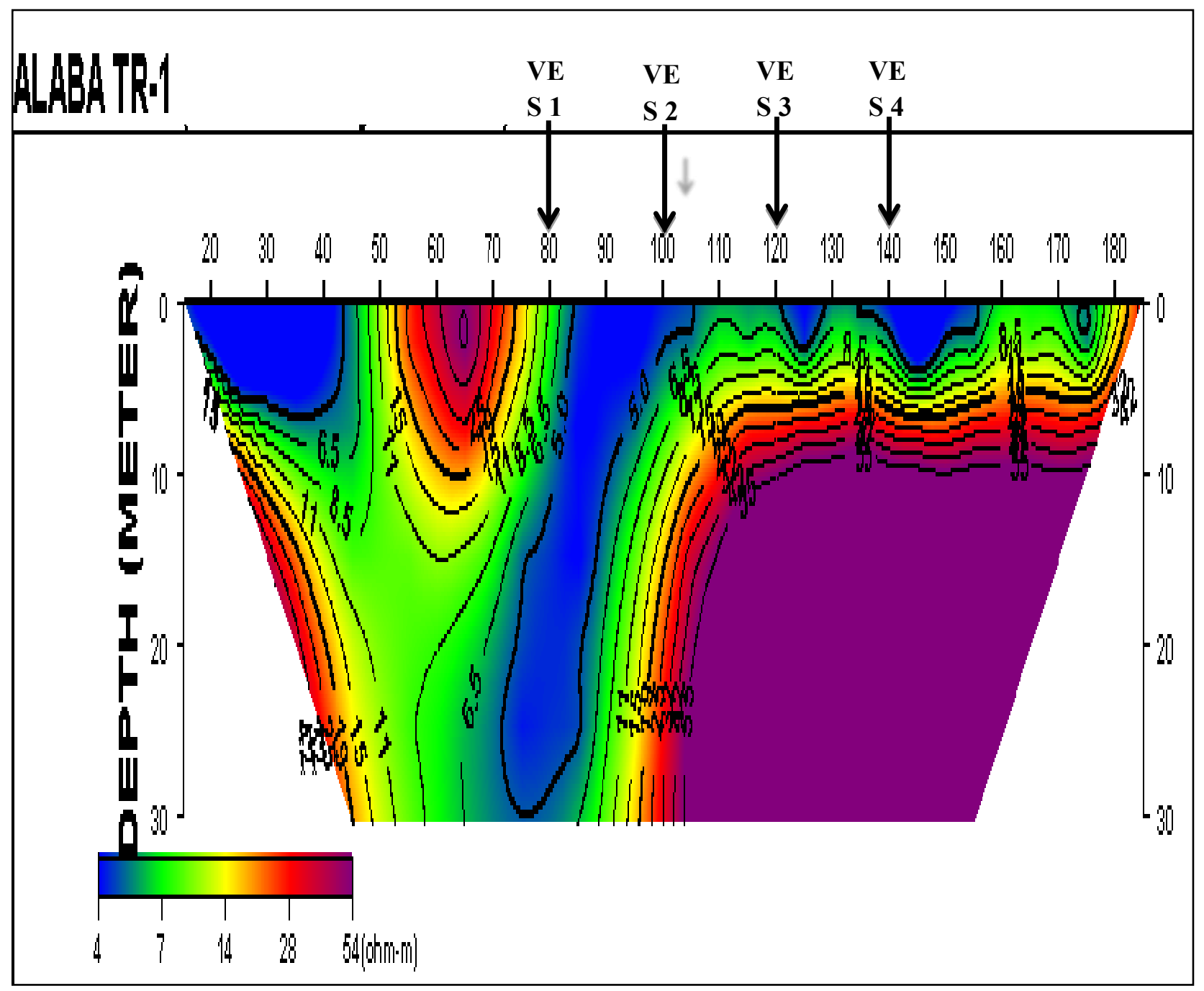

Fig. 4: 2D Wenner for Alaba (profile 1) 
Profile 2: The profile (see Fig. 5) was to the southern flank of the dumpsite along Alaba F-Line Locality 2 (see Fig. 1) where two impacted zones were identified. The first, highly impacted zone of low resistivity values of $5.0-8.3 \Omega \cdot \mathrm{m}$ lies at a lateral distance of about $10-50 \mathrm{~m}$ and occupied the sand column of the subsurface as shown by VES 5 and 6 rights in the middle of the dumpsite and on active locations of e-waste dumping activities. The impacted zone lies at a depth of about $3 \mathrm{~m}$ to more than $15 \mathrm{~m}$. Further to the east of the dumpsite at a lateral distance of $73-90 \mathrm{~m}$, lies the second slightly impacted zone of $11 \Omega \cdot \mathrm{m}$ resistivity value. The zone lies at a depth range of $6-13 \mathrm{~m}$ within the sand column subsurface (VES 7).

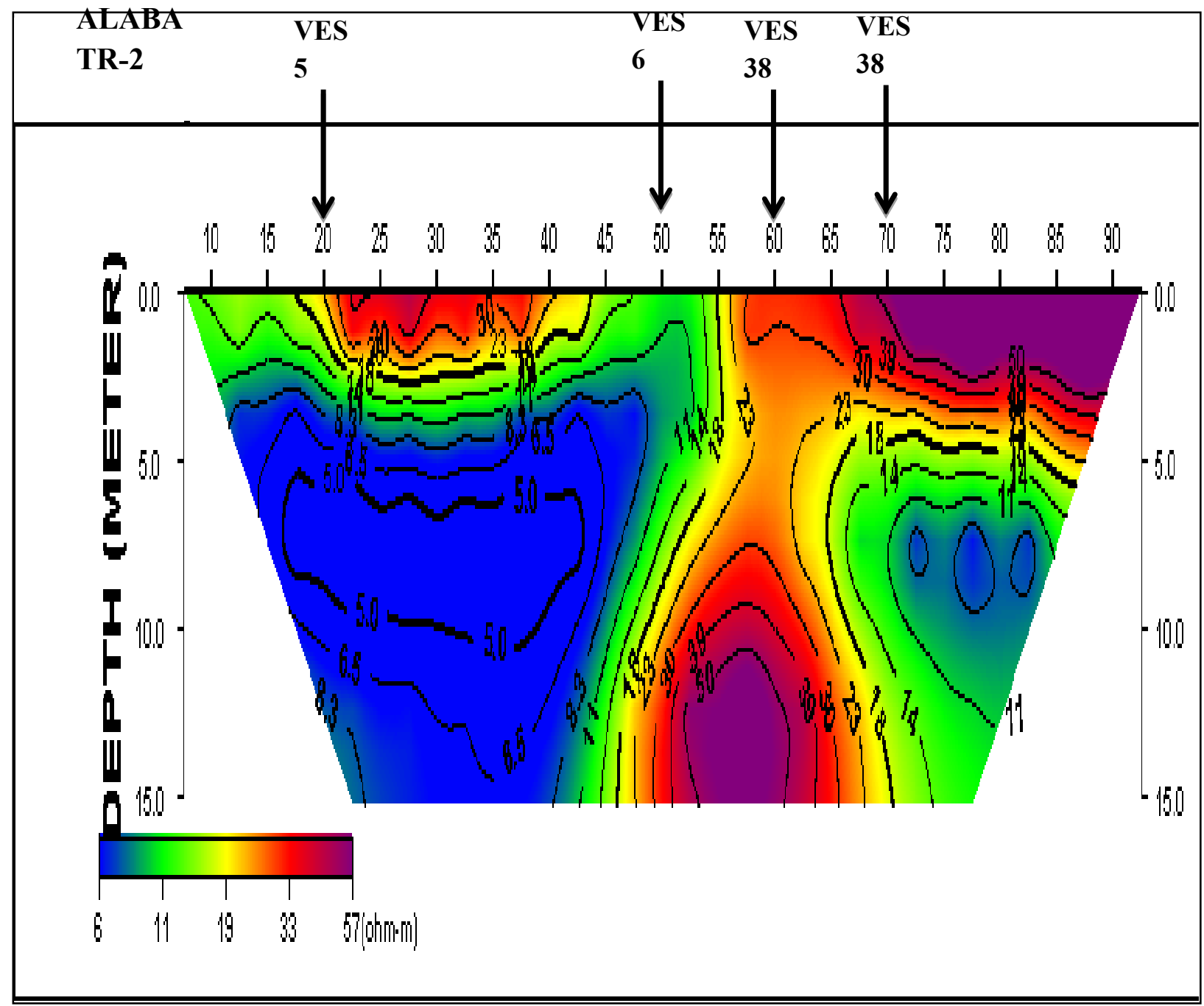

Fig. 5: 2D Wenner for Alaba (profile 2) 
Profile 3: The profile (see Fig. 6) was further north of the dumpsite along Bishop Mathew Street. The area formed part of the dumpsite before it was built up for residential purpose. The profile indicates two impacted zones. The first zone of low resistivity value between 6.5 and $8.3 \Omega \cdot \mathrm{m}$ was observed at a lateral distance of about $50-85 \mathrm{~m}$ and progressively increases in depth through the clayey sand from about $5-20 \mathrm{~m}$ (VES 14). The second zone of low resistivity value between 5.0 and $8.3 \Omega \cdot \mathrm{m}$ was observed at a lateral distance of about $145 \mathrm{~m}$ to more than $180 \mathrm{~m}$. The contaminant progressively increases in depth through the sand column subsurface from about $8 \mathrm{~m}$ to more than $30 \mathrm{~m}$ (VES 16).

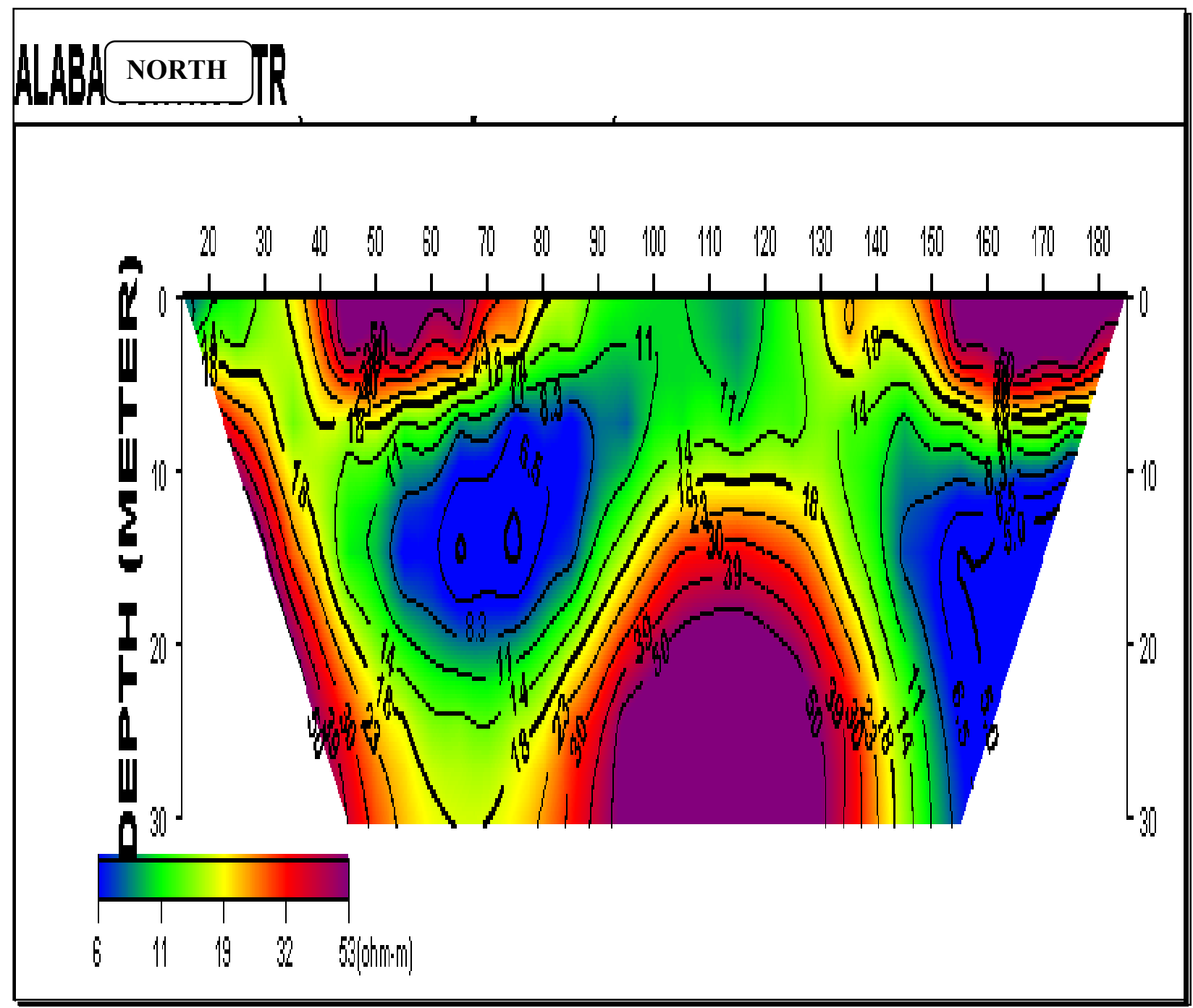

Fig. 6: 2D Wenner for Alaba (profile 3) 


\subsection{Conclusion}

The Alaba subsurface soil has been highly impacted as a result of e-waste dumpsite located in the area and more importantly due to the permeable geoelectric characteristics of the lithologic units beneath the dumpsite. The geoelectric sequence is in agreement with the findings of other researchers which according to Bello et al., (2015) consists of sediment of clay, unconsolidated sands and mud with a varying proportion of vegetable matter along the coastal areas while the alluvial deposit consisted of coarse claying unsorted sand with clay lenses and occasional pebble beds. The lithogy enables the pollutants to spread laterally and progressively increase in depth through the sand column subsurface to more than $30 \mathrm{~m}$.

This study provides information on e-wastes as a major environmental problem in Lagos, Nigeria due to the large influx of e-wastes into open dumpsites in the city. While e-wastes have economic and social benefits in terms of valuable materials they contain and potential job opportunities they offer, e-wastes are also known to be hazardous with concentrations of heavy metals that have the potentials to contaminate the environment and cause adverse health effects on people. The study site is highly populated with wells and boreholes as the main sources of water for the community, thus the findings from this study could facilitate Lagos State Government decisions on improving protection for groundwater resources around the study area and generally in Lagos State in compliance with the environmental policy of the State and its mantra of becoming a smart city. 


\section{ABBREVIATIONS}

EEE: Electrical Electronics Equipment

ECOWAS: Economic Community of West African States

LASEPA: Lagos State Environmental Protection Agency

MMIA: Murtala Muhammed International Airport

UNIDO: United Nation Industrial Development Organisation

UNU: United Nation University

\section{DECLARATIONS}

Availability of data and materials:

All data generated or analysed during this study are included in this published article.

\section{Competing interests:}

The authors declare that they have no competing interests.

\section{Funding:}

Not applicable.

\section{Authors' contribution:}

SE reviewed the data analysis. OL reviewed the survey questionnaire and manuscript. All authors read and approved the final manuscript.

\section{Acknowledgements:}

The authors wish to thank all Field Assistants and others who participated in the study.

\section{Authors' information:}

Not applicable 


\section{References:}

Aizebeokhai, A. P. (2010). 2D and 3D geoelectrical resistivity imaging: Theory and Design. Scientific Research and Essays; 5 (23): 3592 - 3605. http://.www.academicjournals.org/SRE

Akinlalu, A. A.; \& Afolabi, D. O. (2018). Borehole depth determination to freshwater and well design using geophysical logs in coastal regions of Lagos, southwestern Nigeria. Applied Water Science; 8:152

Alabi, A, A.; R, Bello; A. S. Ogungbe; \& H.O. Oyerinde. (2010). Determination of groundwater potential in Lagos State University, Ojo; using geoelectric methods (Vertical Electrical Sounding and horizontal profiling). Report an Opinion: 2 (5). http://www.researchgate.net/publication/285721160

Anudu, G.; Essien, B.; \& Obrike, S. (2014). Hydrogeophysical investigation and estimation of groundwater potentials of the Lower Palaeozoic to Precambrian crystalline basement rocks in Keffi area, North- Central Nigeria, using resistivity methods. Arabian Journal of Geosciences; 7. 10.1007/s12517-012- 0789-x.

Bello, I.; Najib, M.U.; Umar, S. A.; \& Ibrahim, G. G. (2015).Measurement of natural radioactivity concentration at e-waste dumpsite around Alaba International Market, Lagos, Nigeria. Advances in Applied Science Research; 6 (6): 55-64. Available from: https://www.researchgate.net/figure/ [accessed 6 Feb, 2020]

Dulaymi, A. S.; Al-Heety, E. A.; Hussien, B.M. (2012). Geo-Electrical Investigation of Mullusi Aquifer, Rutba, Iraq. International Journal of Geosciences;, 3, 549-564 doi:10.4236/ijg.2012.33056 
Essien, E. E.; Ebeniro, J.O.; Ehirim, C. N. (2020). Determination of hydrogeological parameters from vertical electrical sounding. International Journal of Scientific Research and Engineering Development; 3 (1): 273-279

Leblanc, R. (2018). E-Waste Recycling Facts and Figures. Sustainable Businesses - On-line Recycling Magazine. http://www.the balancesmb.com/sustainability.

Odukoya, A. M. (2015). Geochemical and quality assessment of groundwater in some Nigerian basement complex. International Journal of Environmental Science and Technology; 12 (11): 3643-3656

Ohaegbuchua, H. E., Anyadiegwua, F. C., Odoha, P. O., \& Orji, F. C. (2019). Review of Top Notch Electrode Arrays for Geoelectrical Resistivity Surveys. J. Nig. Soc. Phys. Sci.; 1: 147-155

Okwu, P.I.; \& Onyeje, I. N. (2014). Extraction of valuable substances from e-waste. American Journalof Engineering Research; 3 (1): 299-304

Oladapo, M. I.; Adeoye-Oladapo, O. O.; \& Adebobuyi, F. S. (2013). Geoelectric study of major landfills in the Lagos Metropolitan Area, Southwestern Nigeria. Int. J. Water Res. Environ. Eng.; 5 (7): 387- 398. doi: 10.5897/IJWREE12.02

Ravi, A.; \& Vishnudas, S. (2017). Sustainable Options for Reducing the Waste Footprint in Urban Residential Areas. International Journal of Scientific and Research Publications; $7(7)$

Somoye, E. O. (2017). Variability in the ionosphere as found in life. 54 ${ }^{\text {th }}$ Inaugural lecture; Lagos State University, Ojo, Lagos

The Guardian. (2018). Nigeria generates 1.1million tonnes of e-waste yearly, Gloria Ehiaghe, The Guardian, 2018, May, Technology pp. https://guardian.ng/technology/ 
United Nations Industrial Development Organisation (UNIDO.(2014). Report of UNIDO Country Representative and Regional Director for West Africa at a Stakeholders' Consultative Workshop on Electrical and Electronics Waste Management for Nigeria in Port Harcourt, Rivers State, Nigeria. Source: The Tide Newspapers of $1^{\text {st }}$ December, 2014

United Nations University (UNU). (2017). World e-waste rises 8 percent by weight in 2 years as incomes rise, prices fall: UN-backed report. https://www.sciencedaily.com/releases

Vasantrao, B. M.; Bhaskarrao, P.J.; Mukund, B. A.; Baburao, G. R.; \& Narayan, P. S. (2017). Comparative study of Wenner and Schlumberger electrical resistivity method for groundwater investigation: A case study from Dhule district (M.S.), India. Applied Water Science; 7 (8): 4321-4340.

Zohoori, M.; \& Ghani, A. (2017). Municipal Solid Waste Management Challenges and Problems for Cities in Low-Income and Developing Countries. International Journal of Science and Engineering Applications; 6 (2) 